\title{
An Exploratory Factor Analysis on Generating Teaching and Learning Guiding Principles from Malaysian Teacher Educators' Perspectives
}

\author{
Mazlini Adnan1*, Azwani Masuwai'2, Nor'ain Mohd Tajudin1, Nurulhuda Abdul Rahman1 \\ ${ }^{1}$ Faculty of Science and Mathematics, Sultan Idris Education University, Tanjung Malim, Malaysia \\ ${ }^{2}$ Faculty of Education and Human Development, Sultan Idris Education University, Tanjung Malim, Malaysia \\ Email: ${ }^{\text {mazlini@fsmt.upsi.edu.my }}$
}

Received 10 April 2015; accepted 30 June 2015; published 3 July 2015

Copyright (C) 2015 by authors and Scientific Research Publishing Inc.

This work is licensed under the Creative Commons Attribution International License (CC BY). http://creativecommons.org/licenses/by/4.0/

(c) (i) Open Access

\begin{abstract}
The purpose of this study was to develop and establish the validity and reliability of Teaching and Learning instrument to generate teaching and learning guiding principles. Participants consisted of 171 Malaysian teacher educators. The Teaching and Learning instrument is a 5-point Likertscaled survey consisting of 67 statements and 6 subscales. The internal consistency using Cron-

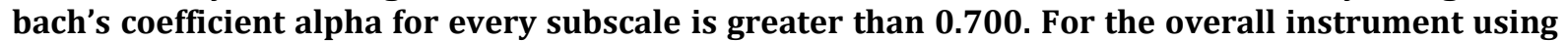
the 67 items that comprised the six subscales, internal consistency reliability analysis revealed a Cronbach's coefficient alpha of 0.977 . Additionally, the varimax rotation was proceeded by maintaining six factors with a total variance contribution of 62.56 percent. Items with factor loading greater than 0.375 were retained. Finally, there were 41 items remaining. However, there were 26 items absent in the original constructs, thus the items were discarded because they were found inappropriate for representing new constructs. The factor analysis found that the teaching and learning guiding principles produced six factors: intellectual excitement (6 items), quality learning spaces (10 items), constructive alignment (8 items), international and culturally (10 items), climate of inquiry (4 items), and nurture good values ( 3 items).
\end{abstract}

\section{Keywords}

Exploratory Factor Analysis, Teaching and Learning, Guiding Principles, Malaysian Teacher Educators

\footnotetext{
${ }^{*}$ Corresponding author.
}

How to cite this paper: Adnan, M., Masuwai, A., Tajudin, N. M., \& Rahman, N. A. (2015). An Exploratory Factor Analysis on Generating Teaching and Learning Guiding Principles from Malaysian Teacher Educators' Perspectives. Creative Education, 6, 1245-1255. http://dx.doi.org/10.4236/ce.2015.612123 


\section{Overview and Background of the Research}

It is acknowledged that teacher education programmes need dynamic development to establish both important core, and the most up-to-date content. At the same time, pedagogies need to change given the changing nature of knowledge, learning, profile of learners and the new environment. A more student-centred rather than teachercentred mode of teaching emphasises the different learning styles and needs of students. It requires the teacher to demonstrate content-pedagogical expertise and also a more definitive understanding of the different learning styles and needs of children and how to address them pedagogically (Futrell, 2010).

However, research by AKEPT (Ministry of Education, 2012) found that 50\% of Malaysian teachers observed failed to deliver their lessons effectively, particularly to inculcate higher order thinking which is one of the six key student attributes as embodied in the National Education Blueprint 2013-2025 (Ministry of Education, 2012). Such ineffective exemplification of teaching among Malaysian teachers warrants immediate attention and appropriate intervention. Therefore, it is crucial for both Sultan Idris Education University (UPSI) and Teacher Training Institutions (IPG) to review their existing teacher education programmes, giving adequate attention, emphasis and focus on the aspect of teaching and learning in the teacher education programmes. This is to enhance and where necessary, to transform their teacher education model so that it will be able to produce teachers for the $21^{\text {st }}$ Century and beyond.

Consequently, measuring teaching and learning guiding principles quantitatively provides teacher educators with a new research direction. This study's findings should be explored further in order to accumulate information on teaching and learning practices in Malaysian classrooms. That information could then be used to design professional development activities compatible with the teaching and learning approaches, teaching and learning experience and subject experts.

The factor analysis of Teaching and Learning instrument must be made through reliable and an essential form. Therefore, it is important to identifying the items load onto particular factors. Hence, the study poses the following research questions, whether the teaching and learning guiding principles achieved an internal reliability with the data collected and to determine the number of factors underlying the variation correlations among the items in Teaching and Learning instrument.

\section{Methodology of the Study}

There are three main aspects of the methodology of the study: sampling, instrument and the data analysis.

\subsection{Sample}

This study involved 171 teacher educators in Malaysia from 18 public universities and two private universities. The respondents had at least five years of experience in teaching and learning, and were pursuing various academic and professional qualifications. The teaching and learning instrument was filled in voluntarily by the teacher educators through online and offline survey.

\subsection{Instrument}

This study focuses on the development of teacher education model for preparing quality teachers for the future. The research involves both qualitative and quantitative research. The project started with the collection of data that were needed to guide the generation of provisional guiding principles for teaching and learning from three sources of data. These sources of data were university websites, research literature on teaching and learning theories, policies and practices, and focus group interviews with key informants.

Collection of data from the first and second sources employed the method of document analysis. The data from the first source consisted of online information gathered from selected university websites from different parts of the world. The universities that were included in this study were based on geographical zones, specifically North America, Europe, Australia, and Asia. Once the geographical zones had been determined, the countries within each zone were selected based on their reputation as providers of teacher education. They were Malaysia, Hong Kong, Singapore, United Kingdom, Finland, United State of America and Australia. This was followed by the selection of universities within each country. These universities consisted of public and private universities. The universities included were ones which provided information about the institutions' teaching and learning guiding principles in their websites. 
The second source of data was the research literature on teaching and learning. The selected research literature was reviewed with a particular focus on theory and practice. Contemporary theories about teaching and learning were compiled and later analysed. The third source of data was the focus group interviews which were conducted with 10 key informants from various sectors such as Ministry of Education officers, university academicians, private sector officers and other stakeholders. The purpose of the focus group interviews was to gather the informants' opinions about aspects of teaching and learning that should be included in planning a teacher education programme and guiding principles for teaching and learning.

Content analysis was conducted on the data gathered from the three sources. The interviews from the third data source were transcribed. All data from the three sources were thematically analysed guided by the inductive approach proposed by Miles and Huberman (1994). Gap analyses were also done to benchmark the Malaysian teaching and learning practices. Elements of gap analysis are current and future state of teaching and learning practices, identification and descriptions of the gap, factors responsible for the gap and remedies, actions and proposals to transform the teaching and learning environment. The content and gap analyses produced a list of elements that are important for teaching and learning. This list was further analysed and classified into themes. The set of 11 themes is shown in Table 1.

From the document analysis, the 11 themes later listed to 6 final themes shows in Table 2. Once the final

\section{Table 1. Set of Teaching and Learning themes.}

No Themes

1

Active role of learners

\section{Example of Teaching and Learning Principles}

Constructivist teachers encourage active, engaged, inquiry -oriented learning enabled by formal and informal assessment of prior student learning and experience by instruction designed in response to those assessment.

2 Cultural sensitivity (importance of understanding how learner differences)

Teachers use differences in student social and cultural backgrounds to design instruction that enhance both teaching and learning.

3 Curricular integration (Strategies to meet individual needs and styles of diverse learners)

Teacher use interdisciplinary curricula to promote student and experience.

4 Multiculturalism

Provide learning experiences that develop inter-culturally capable graduates who can make a difference as socially and ethically responsible global citizens.

$5 \quad$ Critical Reflection and critical review of the learning process and personal experiences of student teachers

Teachers use multiple formal and informal methods to review their teaching and student learning in order to strengthen both.

Candidates know and understand current theory, research and practice that inform the cyclical and interactive process of good teaching (e.g., analysis, preparation, instruction, assessment, and decision making based on assessment results).

$7 \quad$ Technology Integration

Candidates can demonstrate skills in the use of technology appropriate to the respective discipline.

Candidates identify, understand and use and continue to build knowledge in the disciplinary field(s). Candidates apply this knowledge to teaching within the structure of the standards and seek opportunities to continually learn and improve professional practice.

Candidates identify, understand, and use processes to work and advocate cooperatively and professionally, with students/clients, colleagues, parent and community to move toward mutual goals.

Continuously improve teaching practice through academic staff professional development, and critical reflection informed by a range of evaluation approaches.

Value and recognize individual and cultural diversity through the provision of an inclusive context of support and respect for all students. 
Table 2. Set of Teaching and Learning Guiding Principles Constructs.

\begin{tabular}{|c|c|c|c|}
\hline Theme & Name of construct & Amount of item & Number of item \\
\hline $\begin{array}{l}\text { Teaching and learning should foster an atmosphere } \\
\text { of intellectual excitement in students. }\end{array}$ & Intellectual excitement (IE) & 16 items & $\begin{array}{l}\text { Nos. } 1,2,3,4,5,6,7,8,9 \text {, } \\
10,11,12,13,14,15 \text { and } 16\end{array}$ \\
\hline $\begin{array}{l}\text { Teaching and learning should nurture a climate of } \\
\text { inquiry and critical reflection. }\end{array}$ & Quality learning (QL) & 12 items & $\begin{array}{l}\text { Nos. } 17,18,19,20,21,22, \\
23,24,25,26,27 \text { and } 28\end{array}$ \\
\hline $\begin{array}{l}\text { Teaching and learning should ensure a constructive } \\
\text { alignment between an evolving knowledge base, } \\
\text { student learning outcomes, learning experiences, } \\
\text { actual practice, and assessment. }\end{array}$ & $\begin{array}{l}\text { Constructive alignment } \\
\text { (CA) }\end{array}$ & 7 items & $\begin{array}{l}\text { Nos. } 29,30,31,32,33,34 \\
\text { and } 35\end{array}$ \\
\hline $\begin{array}{l}\text { Teaching and learning should offer an international } \\
\text { and culturally diverse learning environment. }\end{array}$ & $\begin{array}{l}\text { International and culturally } \\
\text { (IC) }\end{array}$ & 10 items & $\begin{array}{l}\text { Nos. } 36,37,38,39,40,41 \text {, } \\
42,43,44 \text { and } 45\end{array}$ \\
\hline $\begin{array}{l}\text { Teaching and learning should provide quality } \\
\text { learning spaces, resources and technologies. }\end{array}$ & Climate of inquiry (CI) & 12 items & $\begin{array}{l}\text { Nos. 46, 47, 48, 49, 50, 51, } \\
52,53,54,55,56 \text { and } 57\end{array}$ \\
\hline $\begin{array}{l}\text { Teaching and learning should nurture good values, } \\
\text { attitude and behavior. }\end{array}$ & Nurture good values (NV) & 10 items & $\begin{array}{l}\text { Nos. } 58,59,60,61,62,63 \text {, } \\
64,65,66 \text { and } 67\end{array}$ \\
\hline Total & 6 & 67 items & 67 items \\
\hline
\end{tabular}

themes were obtained, the themes recognized as a constructs that they were used to generate items for a survey which was used to gather information about what local university teacher educators think are important for teaching and learning. Several items were generated for each construct. In the process of generating the items, related literature was consulted. A total of 67 items were generated based on the 6 constructs. The items consist of positive and negative statements. The instrument applies 5-point Likert scale, which is, 1 (Not at all important) to 5 (Extremely important). The survey questionnaire was distributed online and offline to 18 public universities and two private universities and responded by 171 teacher educators. The Table 2 shows the 6 six themes of teaching and learning guiding principles, name of constructs and the amount of items of each constructs.

The questionnaire would provide evidence of the suitability of the items under each theme and to generate constructs of teaching and learning practices. These constructs will later be used to guide the development of provisional guiding principles for teaching and learning in teacher education. An Exploratory Factor Analysis (EFA) was conducted on the items in the questionnaires.

\subsection{Teaching and Learning Guiding Principles}

In this paper, six themes of teaching and learning guiding principles were elected provide the structure and methodology of institutional teaching and learning quality which are interrelated and interdependent. Fundamentally, these principles are based on the National Philosophy of Education, the Philosophy of Teacher Education as well as the National Education Transformation Plan. The principles depict holistic components of the teaching and learning process that reflect the balance of evidence in the research literature on the conditions under which student learning thrives. Each principle has a direct bearing on the quality of students' intellectual development and their overall experience of university life and beyond as they go aboard on a process of lifelong learning. The eventual objective of teaching and learning programs is to prepare quality teachers for future with distinctive attributes that enable them to contribute to ever-changing global context in a meaningful and positive way (University Education Research Laboratory, 2014). Figure 1 shows the teaching and learning guiding principles.

1) Intellectual excitement refers to a state where students are actively engaged in the process and content of learning to the point that they are intellectually stimulated and challenged, intrinsically motivated and find learning to be personally meaningful. Intellectual excitement is probably the most powerful motivating force for students and teachers alike. 2) The quality teaching and learning spaces that encourage and allow a wide range for teaching and learning methods, which accommodate different approaches to teaching and learning across the disciplines, and which have effortlessly integrated electronic technologies. 3) Internationally and culturally diverse learning environment embedded in teaching and learning as the challenges for teachers to manage educational 


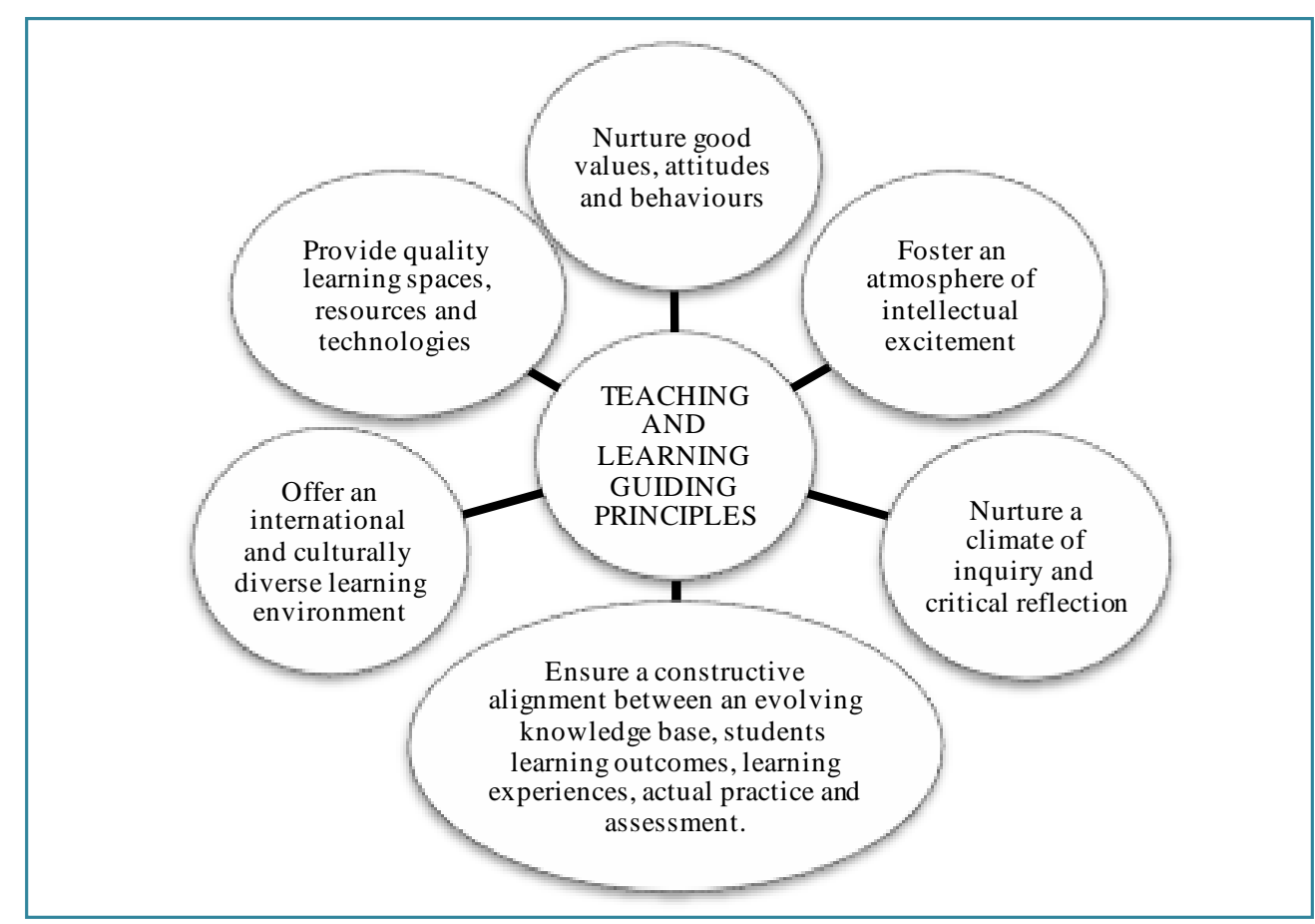

Figure 1. Teaching and learning guiding principles.

processes to make an individual feel supported and learn to explore difference with civility, honesty and fairness. 4) Climate of inquiry is the process to develop the environment of life-long practices of self-discipline, hard work, commitment, and stick-to-itiveness as well as those more subtle practices of looking at problems from multiple perspectives, grappling with ambiguity and recognizing that the truth of things needs deep and abiding exploration. 5) Constructive alignment between developing knowledge base, student learning outcomes, teaching and learning experiences, activities to bridge knowledge, practice and assessment. It is a balancing between all the elements in teaching and learning for actual practice. 6) Our own values and beliefs have a critical impact on the way we make decisions, design programs and conduct ourselves. The discipline-specific values, one must be spirituality brawny in his or her beliefs as the foundation for living. Possess the courage, the discipline, and the will to do the right things are the need to integrity (University Education Research Laboratory, 2014).

\subsection{Limitation of the Study}

This paper is limited to teacher educators in the higher education institutions in Malaysia from 18 public universities and two private universities focusing on teacher education programmes. Thus the outcome of this research cannot be generalized to other groups of teacher. The paper also only focused on six Teaching and Learning Guiding Principles earlier which provide the structure and methodology of institutional teaching and learning excellence. Hence, the results obtained may not bring the same effect in future due to higher education and more widespread of guiding principles in teaching and learning.

\subsection{Data Analysis}

The data were analysed using the SPSS 11.5 software. Generating teaching and learning guiding principles, which comprised 67 suggested items, was analysed using a factor analysis. The factor analysis has been used to ensure the particular factors contained items suitable in the context of the generating teaching and learning guiding principles (Chua, 2009; Tabachnick \& Fidell, 2001).

\section{Findings of the Study}

The overall mean score for the instrument in this study is 4.07 with a standard deviation of 0.526 . Table 3 shows 
the mean, standard deviation, and Cronbach's alpha for each construct. The internal consistencies (alpha coefficients) are $0.923,0.924,0.909,0.919,0.933$ and 0.866 respectively for the constructs of generate teaching and learning guiding principles; intellectual excitement, quality learning spaces, constructive alignment, international and culturally, climate of inquiry, and nurture good values. The overall value of Cronbach's alpha for this Generating teaching and learning guiding principles study is 0.977. According to Konting (2004) and Ghafar (1999), a Cronbach's alpha value of at least 0.6 must be obtained for the instrument to be suitable for use.

The factor analysis was begun by conducting Bartlett's Test of Sphericity and the Kaiser-Meyer-Olkin Measure of Sampling Adequacy Test (KMO). Bartlett's Test of Sphericity has been used to identify whether the correlation between the items is adequate for the carrying out of factor analysis. In this study, the test results are significant $\left(\chi^{2}=10391.64 ; p<0.00\right)$, showing that the correlation between the items is adequate, The KMO test has been used to identify the items that are appropriate for the factor analysis. In other words, it determines whether the sampling is adequate before proceeding to the next stage of factor analysis (Maat et al., 2011). A factor analysis is deemed appropriate if the value of KMO is greater than 0.60 (Chua, 2009; Som, 2005; Tabachnick \& Fidell, 2001).

In this study, the KMO value is 0.915 . Thus, the items in the generating teaching and learning guiding principles have been shown to be sufficient to proceed to the factor analysis. There are 6factors that give eigenvalues of greater than 1. All the six factors contribute a total of 62.56 percent of overall variance shift (Generating teaching and learning guiding principles). Also, the other factors contributed only a total of 37.44 percent variance of dependent variable. Based on those findings, the research proceeded to varimax rotation retaining the six factors with a total variance contribution of 62.56 percent. The numbers of samples in this study are 171, a factor loading of 0.375 is employed. In that case, the item with factor loading greater than 0.375 were retained. Finally, there are a total of 41 items left and the factor analysis results have found that the generate teaching and learning guiding principles produced six factors. The final items in the generate teaching and learning guiding principles with their factor loading are shown in Table 4.

\section{Conclusion}

The factor analysis result has demonstrated that there are six main factors in generating teaching and learning guiding principles. The six constructs are intellectual excitement (six items), quality learning spaces (ten items), constructive alignment (eight items), international and culturally (ten items), climate of inquiry (four items), and nurture good values (three items). However, there are discarded items because they produced low factor loading; cross-loaded items; and are inappropriate for the new construct.

\section{Acknowledgements}

We would like to thank Ministry of Education Malaysia for providing the funds under the Niche Research Grant Scheme (NRGS): 2014-0001-107-82-2 and Sultan Idris Education University for providing the official approval that enable us to do the research.

Table 3. Set of Teaching and Learning Guiding Principles Constructs.

\begin{tabular}{|c|c|c|c|}
\hline Constructs & Mean & Standard Deviation & Reliability \\
\hline - Intellectual excitement & 4.00 & 0.581 & 0.923 \\
\hline - Quality learning spaces & 4.10 & 0.637 & 0.924 \\
\hline - Constructive alignment & 4.23 & 0.600 & 0.909 \\
\hline - International and culturally & 3.86 & 0.682 & 0.919 \\
\hline - Climate of inquiry & 4.08 & 0.603 & 0.933 \\
\hline - $\quad$ Nurture good values & 4.23 & 0.526 & 0.866 \\
\hline Total & 4.07 & 0.526 & 0.977 \\
\hline
\end{tabular}


Table 4. Items in generate teaching and learning guiding principles with their factor loading.

\begin{tabular}{|c|c|c|c|c|c|c|}
\hline \multirow[t]{2}{*}{ Item } & \multicolumn{6}{|c|}{ Component } \\
\hline & 1 & 2 & 3 & 4 & 5 & 6 \\
\hline TNL62 & 0.763 & & & & & \\
\hline TNL63 & 0.749 & & & & & \\
\hline TNL54 & 0.731 & & & & & \\
\hline TNL30 & 0.640 & & & & & \\
\hline TNL66 & 0.635 & & & & & \\
\hline TNL29 & 0.602 & & & & & \\
\hline TNL45 & & 0.778 & & & & \\
\hline TNL42 & & 0.746 & & & & \\
\hline TNL43 & & 0.743 & & & & \\
\hline TNL65 & & 0.690 & & & & \\
\hline TNL39 & & 0.660 & & & & \\
\hline TNL44 & & 0.636 & & & & \\
\hline TNL41 & & 0.633 & & & & \\
\hline TNL36 & & 0.632 & & & & \\
\hline TNL38 & & 0.541 & & & & \\
\hline TNL40 & & 0.511 & & & & \\
\hline TNL27 & & & 0.740 & & & \\
\hline TNL26 & & & 0.726 & & & \\
\hline TNL25 & & & 0.680 & & & \\
\hline TNL21 & & & 0.677 & & & \\
\hline TNL24 & & & 0.675 & & & \\
\hline TNL28 & & & 0.568 & & & \\
\hline TNL23 & & & 0.535 & & & \\
\hline TNL18 & & & 0.484 & & & \\
\hline TNL3 & & & & 0.733 & & \\
\hline TNL2 & & & & 0.673 & & \\
\hline TNL4 & & & & 0.669 & & \\
\hline TNL1 & & & & 0.626 & & \\
\hline TNL5 & & & & 0.617 & & \\
\hline TNL7 & & & & 0.583 & & \\
\hline TNL12 & & & & 0.573 & & \\
\hline TNL13 & & & & 0.565 & & \\
\hline TNL16 & & & & 0.529 & & \\
\hline TNL15 & & & & 0.432 & & \\
\hline TNL60 & & & & & 0.580 & \\
\hline TNL10 & & & & & 0.521 & \\
\hline TNL35 & & & & & 0.516 & \\
\hline TNL64 & & & & & 0.430 & \\
\hline TNL8 & & & & & & 0.619 \\
\hline TNL67 & & & & & & 0.513 \\
\hline TNL55 & & & & & & 0.547 \\
\hline
\end{tabular}




\section{References}

Chua, Y. P. (2009). Advanced Research Statistics: Regression Test, Factor Analysis and SEM Analysis. New York: McGraw-Hill Education.

Futrell, M. (2010). Transforming Teacher Education to Reform America’s P-20 Education System. Journal of Teacher Education, 6, 432-440. http://dx.doi.org/10.1177/0022487110375803

Ghafar, M. N. (1999). Penyelidikan Pendidikan. Johor Bahru: Universiti Teknologi Malaysia.

Konting, M. M. (2004). Kaedah penyelidikan pendidikan. Kuala Lumpur: Dewan Bahasa dan Pustaka.

Maat, S. M., Zakaria, E., \& Nordin, N. M. (2011). A Confirmatory Factor Analysis of Mathematics Beliefs Scale in a Malaysian Context. Australian Journal of Basic \& Applied Sciences, 5, 555-560.

Miles, M. B., \& Huberman, A. M. (1994). Qualitative Data Analysis: An Expanded Sourcebook. Thousand Oaks, CA: Sage Publications.

Ministry of Education (2012). Laporan Awal Pelan Pembangunan Pendidikan 2013-2025. www.moe.gov.my/userfiles/file/PPP/Preliminary-Blueprint-BM.pdf

Som, H. M. (2005). Panduan Mudah Analisis Data Menggunakan SPSS Window. Johor Bahru: Universiti Teknologi Malaysia.

Tabachnick, B. G., \& Fidell, L. S. (2001). Using Multivariate Analysis. Northridge: California State University, Harper Collins College Publishers.

University Education Research Laboratory (2014). Retrieved on June 1 ${ }^{\text {st }}, 2015$ from http://www.uerl.upsi.edu.my/ 


\section{Appendix}

Instruction: Please tick $[\sqrt{ }]$ in the appropriate box.

Arahan: Silatandakan $[\checkmark]$ di dalamkotak yang berkenaan.

Based on your opinion, rate how important each of the listed items is for teaching and learning. Use the following scale:
1) Not at all important;
2) Slightly important;
3) Moderately important;
4) Very important;
5) Extremely important.

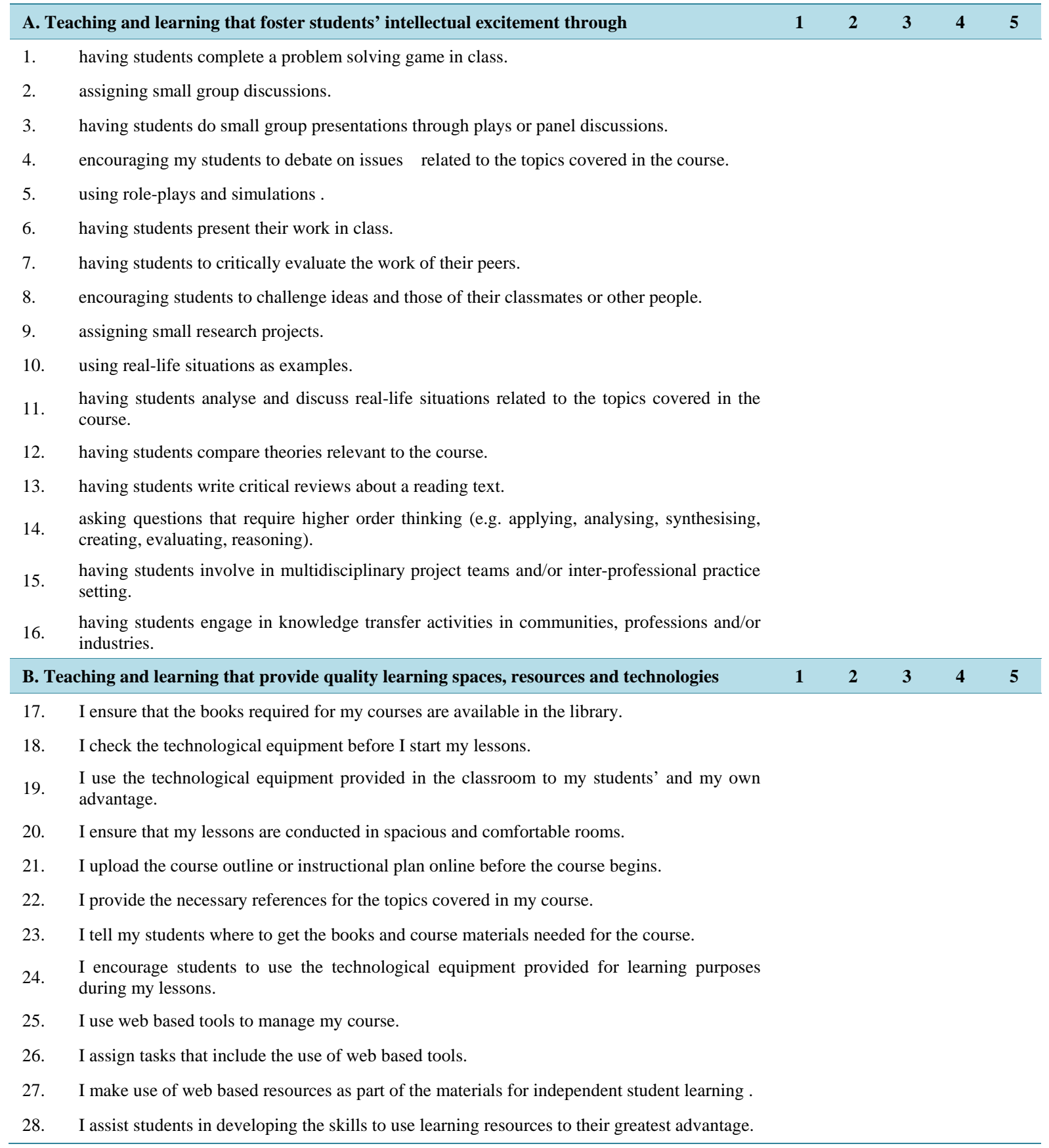




\section{Continued}

C. Teaching and learning that ensure a constructive alignment between an evolving knowledge base, student learning outcomes, teaching and learning experiences, activities to bridge knowledge and practice and assessment

29. I relate new content to previously-learned content.

30. I use the learning outcomes that I have set for my students to guide me in planning the teaching content and activities for each lesson.

31. I ensure that the content and activities for each lesson are appropriate to the topic of the lesson.

32. I provide appropriate tasks and activities to assess my students' learning in every lesson.

33. I use a variety of assessment materials in my lessons.

34. I ask my students to relate the theories learned to real-life situations.

35. I assign tasks which require my students to apply what they have learned to real-life situations.

D. Teaching and learning that offer an international and culturally diverse learning environment

36. I ensure that students from different cultural backgrounds are represented when engaging in group work.

37. I use examples relevant to different cultures when explaining a topic in class.

38. I give tasks or assignments that encourage my students to draw from their own experiences.

39. I encourage my students to share their views and ideas from their own cultural perspectives.

40. I use books and materials produced by writers from different countries in my course.

41. I use resources available in the internet to connect my students to students from other countries.

42. I encourage students to participate in exchange student programmes.

43. I guide students in organising local and international programmes.

44. I encourage students to participate in local and international events.

45. I encourage students to participate in local and international charity or volunteering work.

E. Teaching and learning that nurture a climate of inquiry and critical reflection

46. I assign small research projects for my course.

47. I include a question that requires my students to reflect on what they have done or learned and to suggest ways for improvement in my assignments.

48. I prepare experiments or investigative assignments for relevant topics.

49. I ask my students to write a critical reflection on their own experiences.

50. I plan hands-on experience for my students through the tasks and assignments for each topic.

51. I demonstrate a willingness to revise my own views and admit error, and encourage this attitude in students.

52. I use evidence-based teaching practices in my classroom.

53. I encourage students to ask questions.

54. I ask questions which are open and reflective in nature.

55. I provide opportunities for students to critically evaluate and contribute to the scholarly discourse on practice.

56. I conduct research in teaching and learning to inform my own practices.

57. I demonstrate a commitment to improving my practice through critical reflection and professional development. 


\section{Continued}

58. I get students to cooperate with each other through pair work or small group work.

59. I model good working habits when conducting my lessons.

60. I employ the procedure for dealing with absenteeism prescribed by my institution.

61. I make clear to my students the level of quality that I value in their work.

62. I show genuine enthusiasm when teaching the topics in my course.

63. I use positive language to encourage my students to improve.

64. My students and I set a procedure for managing bad behaviour.

65. I plan and carry out charity and volunteering activities for the community with my students.

66. I remind my students not to plagiarise.

67. I encourage my students to fall back on their beliefs when they feel discouraged in their studies.

THANK YOU 